DOI: $10.15193 /$ zntj/2019/121/315

\author{
ANNA ŁEPECKA, DOROTA ZIELIŃSKA, MONIKA BREJNAK, \\ ALEKSANDRA OŁDAK, DANUTA KOŁOŻYN-KRAJEWSKA
}

\title{
TECHNOLOGICAL PROPERTIES OF LACTOBACILLUS RHAMNOSUS K3 ISOLATED FROM FERMENTED CABBAGE AND ITS POTENTIAL USE AS STARTER CULTURE FOR FERMENTED FOOD PRODUCTS
}

\author{
S u m m a r y
}

The objective of the research study was to specify technological properties of the Lactobacillus rhamnosus $\mathrm{K} 3$ strain. This bacterial strain was tested for its ability to grow under the processing conditions, such as temperature $\left[{ }^{\circ} \mathrm{C}\right]: 10,15,45, \mathrm{pH}$ value: $3.9,6.4,9.6$, and a high $\mathrm{NaCl}$ concentration $[\%]: 5,8,10$. Biochemical tests (sugar fermentation and enzyme activity) were carried out and the survival of those bacteria was assayed in the medium depending on the type of food (milk, tomato juice, and beef broth). Milk fermented with Lb. rhamnosus K3 was subjected to 6-week incubation. The results showed that the Lb. rhamnosus $\mathrm{K} 3$ strain was able to grow at different temperatures but within a narrow $\mathrm{pH}$ range. The bacterial strain did not tolerate high $\mathrm{NaCl}$ concentrations, however it grew well in any kind of food medium. A particularly good bacterial growth was observed in milk. Lb. rhamnosus $\mathrm{K} 3$ was able to metabolize sugars. This strain did not reduce nitrates; no catalase activity was detected either. The $\beta$-galactosidase enzyme was identified. The best temperature of milk fermentation was proved to be $37^{\circ} \mathrm{C}$. It was also found that $L b$. rhamnosus $\mathrm{K} 3$ had functional properties allowing its use as a starter culture for milk. The number of bacterial cells remained at a level higher than $8 \log \mathrm{CFU} / \mathrm{ml}$ throughout the entire 6-week incubation of refrigeration storage $\left(4^{\circ} \mathrm{C}\right)$. The bacteria of Lactobacillus rhamnosus $\mathrm{K} 3$ were capable of fermenting milk confirming their suitability as a starter culture for milk products.

Key words: lactic acid bacteria (LAB), Lactobacillus rhamnosus, technological properties, fermented food products

\section{Introduction}

There is an increasing tendency among consumers to prefer food products that contain no chemical additives [1]. This creates a need to explore new technologies or

Dr inż. A. Łepecka, dr hab. inż. D. Zielińska, mgr inż. M. Brejnak, mgr inż. A. Otdak, prof. dr hab. D. Kotożyn-Krajewska, Katedra Technologii Gastronomicznej i Higieny Żywności, Instytut Nauk o Żywieniu Człowieka, Szkoła Glówna Gospodarstwa Wiejskiego w Warszawie, ul. Nowoursynowska 159 C,02-776 Warszawa. Kontakt: anna_lepecka@sggw.pl 
to employ old traditional techniques. Fermentation is one of the oldest methods of food preservation. This process can occur spontaneously when it is run by indigenous microflora present in the raw material or non-spontaneously with starter cultures added. The use of specific strains can result in the significant improvement of the product quality [12].

The main function of starter cultures is to produce fermented products with good sensory characteristics and capable of inhibiting the growth of pathogenic microflora. The fermented food products have high potential as functional foods because of certain $\mathrm{LAB}$, which commonly produce health-promoting agents and bioactive compounds (i.e. organic acids, bioactive peptides, $\mathrm{H}_{2} \mathrm{O}_{2}$ and bacteriocins) during the fermentation process [6].

A starter culture is defined as a preparation containing large numbers of variable microorganisms, which may be added to food to accelerate the fermentation process [8]. Using lactic acid bacteria strains as starter cultures for food is not a new concept. However, there is a new idea of seeking technologically attractive and healthpromoting microorganisms in various natural sources. Major sources of those novel microorganisms comprise fermented and non-fermented milk, meat, cereal and vegetables $[6,9,21,28,29]$.

Strains isolated directly from food are probably the best to be used as starter cultures for food as they are well-adapted to various conditions. Moreover, a variety of potential probiotic microorganisms, including strains isolated from food, have been successfully applied as starter cultures in various types of food products [1,9]. The first stage of selecting a strain is to identify it. There are also performed tests to confirm the safety and to assess the usefulness of the technology to be applied. This assessment covers the study on the following: growing temperature and $\mathrm{pH}$ level, growing concentrations of $\mathrm{NaCl}$, the ability to cause the fermentation of sugars and metabolism of certain compounds. A safe and functional strain can be used as a starter culture in food. It is also necessary to check the survival of the strain and to confirm its presence in the final product. The successful application of LAB strains in food depends on their intrinsic ability to survive in final products [3].

Considering the potentially probiotic properties of the Lactobacillus rhamnosus K3 strain, it was tested, under this research study, for its technological properties. The objective of the research study was to specify technological properties of the Lactobacillus rhamnosus $\mathrm{K} 3$ strain.

\section{Material and methods}

Lactobacillus rhamnosus $\mathrm{K} 3$ is a strain isolated from fermented cabbage, although the Lb. plantarum and Lb. brevis strains are those commonly isolated from this source $[13,15]$. The identification (GenBank accession KM186164) and selected pro- 
biotic properties were confirmed in the previous studies by Zielińska et al. [29]. $L b$. rhamnosus $\mathrm{K} 3$ presented a high survival rate at a low $\mathrm{pH}$ level in a simulated gastrointestinal tract model (GIT), it exhibited resistance to high concentrations of bile salts and showed a moderate hydrophobicity value; also it showed susceptibility to common antibiotics and did not produce harmful enzymes.

The whole culture of bacteria was kept at $-80{ }^{\circ} \mathrm{C}$. The bacterial cultures were cultivated for $24 \mathrm{~h}$ on MRS broth (LabM, United Kingdom) under the aerobic conditions at $37{ }^{\circ} \mathrm{C}$ and tested for their technological properties [29]. Also, while studying the viability of those bacterial cultures, they were cultivated on a solid medium MRS agar (LabM, United Kingdom) according to PN-ISO 15214:2002 [19]. All experiments were performed in 3 replications.

Each time $9 \mathrm{ml}$ of fresh MRS broth was inoculated in $0.1 \mathrm{ml}$ of 24-hour culture on MRS broth. The cell cultures were incubated at $\left[{ }^{\circ} \mathrm{C}\right]: 10,15$ and 45 [23]. The optical density of the culture was measured after $24 \mathrm{~h}$ using a Genesys ${ }^{\mathrm{TM}} 20$ spectrophotometer (Thermo Scientific, USA) at a wavelength of $600 \mathrm{~nm}$. The strain growth was defined as: $\mathrm{OD}_{600}<2.000$ - very good growth; $\mathrm{OD}_{600} 1.000$ - 1.999 - good growth; $\mathrm{OD}_{600}$ 0.600 - 0.999 - moderate growth; $\mathrm{OD}_{600}>0.599$ - no growth. Each time $0.1 \mathrm{ml}$ of $24-$ hour culture on MRS broth was added to $9 \mathrm{ml}$ of fresh MRS broth adjusted to a $\mathrm{pH}$ level of 3.9, 6.4 and 9.6 with $1 \mathrm{M} \mathrm{HCl}$ and $1 \mathrm{M} \mathrm{NaOH}$ (Sigma Aldrich, Poland) [23]. The cell cultures were incubated at $37^{\circ} \mathrm{C}$. The optical density of the culture was measured after $24 \mathrm{~h}$ by the same spectrophotometer.

Each time $0.1 \mathrm{ml}$ of 24-hour culture on MRS broth was added to $9 \mathrm{ml}$ of fresh MRS broth and supplemented with [\%]: 5, 8 and 10 concentrations of $\mathrm{NaCl}$ (Sigma Aldrich, Poland). The controls consisted of MRS broth cultures without $\mathrm{NaCl}$ added. The cell cultures were incubated at $37^{\circ} \mathrm{C}$. The optical density of the cultures was measured every $3 \mathrm{~h}$ during a period of $24 \mathrm{~h}$ with the use of the same spectrophotometer [23].

The strain was subjected to sugar fermentation and enzyme activity; HiBacillus (HiMedia, India) test kits were used to perform general screening. The test was done in accordance with the manufacturer's instructions. The cultures were cultivated for $24 \mathrm{~h}$ in a $5 \mathrm{ml}$ MRS broth (LabM, United Kingdom) at $37{ }^{\circ} \mathrm{C}$. Then $0.05 \mathrm{ml}$ of MRS broth culture was transferred to the surface of each of 12 substrates. The kits were incubated again at $37^{\circ} \mathrm{C}$ for $24 \mathrm{~h}$. After that time reagents were added and after 5 min the results were read. They are presented as $(+)$ positive reaction or (-) negative reaction.

The $L b$. rhamnosus $K 3$ strain was cultivated for $24 \mathrm{~h}$ on MRS broth under the anaerobic conditions at $37^{\circ} \mathrm{C}$. Then $0.1 \mathrm{ml}$ of the MRS broth cultures were centrifuged, washed twice with a PBS solution (BioMaxima, Poland) and transferred to $9 \mathrm{ml}$ of UHT milk $3.2 \%$ fat (Mlekovita, Poland), tomato juice (Hortex, Poland), beef broth 
[16] and MRS broth (as control medium; LabM, United Kingdon). The medium tested represented different food matrices. The cell cultures were incubated at $37^{\circ} \mathrm{C}$ for $24 \mathrm{~h}$.

Each time a tube containing $10 \mathrm{ml}$ of UHT milk $3.2 \%$ fat (Mlekovita, Poland) was $1 \%(\mathrm{v} / \mathrm{v})$ inoculated with the $L b$. rhamnosus $\mathrm{K} 3$ strain. The $\mathrm{pH}$ value was measured immediately after inoculation and after $24 \mathrm{~h}$ of incubation at $37^{\circ} \mathrm{C}$; it was presented as $\Delta \mathrm{pH}[20]$ :

$$
\Delta \mathrm{pH}=\mathrm{pH}_{0}-\mathrm{pH}_{24}
$$

$\mathrm{pH}_{0}-\mathrm{pH}$ value after inoculation (time 0 );

$\mathrm{pH}_{24}-\mathrm{pH}$ value after incubation (time 24).

Each time $0.1 \mathrm{ml}$ of 24-hour MRS broth cultures (at a concentration of $10^{9}$ $\mathrm{CFU} / \mathrm{ml}$ ) were centrifuged, washed twice with PBS and added to $200 \mathrm{ml}$ of UHT milk $3.2 \%$ fat. The samples were incubated at three different temperatures $\left[{ }^{\circ} \mathrm{C}\right]: 25,30$ and 37 for $48 \mathrm{~h}$ to select optimal conditions for fermentation. After incubation a bacterial cells enumeration was carried out by spread-plating decimal dilutions onto MRS agar.

The number of bacterial cells of Lb. rhamnosus K3 strain was verified immediately after fermentation (at $37^{\circ} \mathrm{C}$ for $48 \mathrm{~h}$ ) and every week during the 6-week storage at $\left[{ }^{\circ} \mathrm{C}\right]: 4,25$ and 37; then decimal dilutions were spread-plated onto MRS agar. The temperatures were selected to simulate both the storage conditions (in refrigerator at $4{ }^{\circ} \mathrm{C}$ and at a temperature of $25^{\circ} \mathrm{C}$ ) and the extension of the fermentation process. The assay is of a model nature. The $\mathrm{pH}$ values of the milk samples were measured using a $\mathrm{pH}-$ meter of Elmetron CP-501 type (Elmetron, Poland).

A statistical analysis was performed using Microsoft Excel 2013 and Statistica 13 (StatSoft). The error bars on graphs show the standard deviation. Statistical tests were used to determine the effect of various factors on the survival of bacterial cells. The data were analysed using an analysis of variance (ANOVA) and a Student t-test. The differences were considered significant at $\mathrm{p}<0.05$.

\section{Results and discussion}

Temperature affects microorganisms both directly and indirectly. The direct action is the impact on the chemical composition of cells, their growth rate, nutritional requirements and activity of the enzymes. Temperature affects indirectly the growth of microorganisms by changing their osmotic properties, affecting cell membranes and ion transportation, regulating solubility and diffusion of the molecules of chemical substances [27]. The effects of different temperatures on the growth of Lb. rhamnosus K3 in MRS broth are presented in Tab. 1.

The largest increase was observed at $37^{\circ} \mathrm{C}$. Low temperatures tend to reduce growth rates, however a good growth was reported at a temperature of $10^{\circ} \mathrm{C}$ and $15{ }^{\circ} \mathrm{C}$, and no growth at $45^{\circ} \mathrm{C}$. The optimum temperature for mesophilic bacteria to grow is 
$20-40^{\circ} \mathrm{C}$. Like most mesophilic bacteria, the Lb. rhamnosus $\mathrm{K} 3$ strain does not grow at $45^{\circ} \mathrm{C}$. The results were similar to those as reported by Sahnouni et al. [21]. The Lactobacillus strains were not able to grow at a temperature of $40{ }^{\circ} \mathrm{C}$ and $45^{\circ} \mathrm{C}$ but their growth at a temperature of $10{ }^{\circ} \mathrm{C}$ and $15^{\circ} \mathrm{C}$ was good.

Table 1. Effect of temperature and $\mathrm{pH}$ value on growth of Lb. rhamnosus K3 in MRS broth Tabela 1. Wpływ temperatury i $\mathrm{pH}$ na wzrost $L b$. rhamnosus $\mathrm{K} 3 \mathrm{w}$ bulionie MRS

\begin{tabular}{|c|c|c|c|c|c|c|c||}
\hline \hline \multirow{2}{*}{$\begin{array}{c}\text { Specification } \\
\text { Wyszczególnienie }\end{array}$} & \multicolumn{3}{|c|}{$\begin{array}{c}\text { Growth at different temperatures } \\
\text { Wzrost w różnych temperaturach }\end{array}$} & \multicolumn{3}{c|}{$\begin{array}{c}\text { Growth at different } \mathrm{pH} \text { level } \\
\text { Wzrost w różnym } \mathrm{pH}\end{array}$} \\
\cline { 2 - 9 } & $10^{\circ} \mathrm{C}$ & $15^{\circ} \mathrm{C}$ & $37^{\circ} \mathrm{C}$ & $45^{\circ} \mathrm{C}$ & 3.9 & 6.4 & 9.6 \\
\hline \multirow{2}{*}{$\mathrm{OD}_{600}$} & 1.700 & 1.837 & 2.198 & 0.530 & 0.471 & 2.198 & 0.800 \\
& \pm 0.33 & \pm 0.36 & \pm 0.00 & \pm 0.17 & \pm 0.05 & \pm 0.00 & \pm 0.05 \\
\hline Growth / Wzrost & + & + & ++ & - & - & ++ & $+/-$ \\
\hline
\end{tabular}

Explanatory notes / Objaśnienia:

Table shows mean values \pm standard deviations / w tabeli przedstawiono wartości średnie \pm odchylenia standardowe; $\mathrm{n}=3 ; \mathrm{OD}_{600}$ - optic density at wavelength of $600 \mathrm{~nm} /$ gęstość optyczna przy długości fali $600 \mathrm{~nm} ;(++)$ - very good growth / bardzo dobry wzrost, $(+)$ - good growth / dobry wzrost, $(+/-)$ - moderate growth / umiarkowany wzrost, (-) - no growth / brak wzrostu.

Lactic acid bacteria have a great ability to adapt to the environment. The development of microorganisms in the environments of a $\mathrm{pH}$ range is possible by maintaining the intracellular concentration of hydrogen ions at a level close to neutral [27]. In this research study no growth of Lb. rhamnosus $\mathrm{K} 3$ was found at a low $\mathrm{pH}$ level (3.9), however this growth was moderate at a basic $\mathrm{pH}$ level (9.6). A very good growth was observed at $\mathrm{pH}$ equalling 6.4 ( $\mathrm{pH}$ of MRS broth) - Tab. 1.

Stress tolerance is correlated with the conditions prevalent in a specific habitat of LAB strains [16]. The effect of high $\mathrm{NaCl}$ concentration on the growth of $L b$. rhamnosus $\mathrm{K} 3$ is shown in Fig. 1. The addition of $8 \%$ and $10 \% \mathrm{NaCl}$ had a significant effect on the growth of the strain. Lb. rhamnosus $\mathrm{K} 3$ did not tolerate any high $\mathrm{NaCl}$ addition. MRS broth culture without $\mathrm{NaCl}$ added (control) reached a steady increase in the bacterial cells. The largest growth was recorded after about $12 \mathrm{~h}$ of incubation. In the $\mathrm{Ng}$ et al. study [17] it was noted that the Lactobacillus strains isolated from the Malaysian traditional fermented food were resistant to MRS broth at $4 \% \mathrm{NaCl}$, however a suppression was detected at $6 \% \mathrm{NaCl}$. The ability to tolerate osmotic stress is species- or even strain-specific.

Though the assays were performed under the model conditions, the results could be referred to food matrices. It is possible to use this strain as a starter culture in a close to neutral environment (e.g. meat or milk) at a low salt concentration $(<5 \%)$ and within a broad spectrum of fermentation temperatures $\left(10-37^{\circ} \mathrm{C}\right)$. 


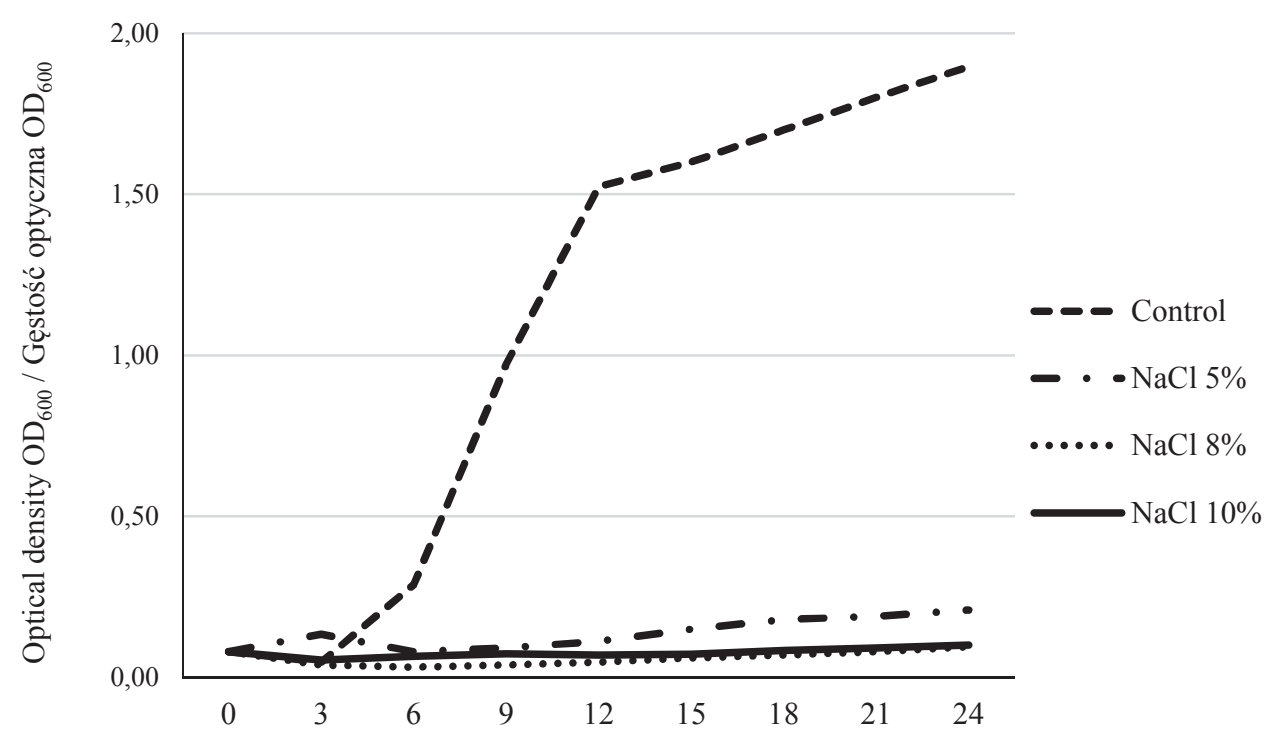

Time / Czas [h]

Explanatory notes / Objaśnienia:

$\mathrm{n}=3$; control - control sample / próba kontrolna.

Fig. 1. Effect of $\mathrm{NaCl}$ concentration on growth of Lb. rhamnosus $\mathrm{K} 3$

Rys. 1. Wpływ stężenia $\mathrm{NaCl}$ na wzrost Lb. rhamnosus $\mathrm{K} 3$

Table 2. Biochemical tests for Lb. rhamnosus K3 strain

Tabela 2. Testy biochemiczne dla szczepu Lb. rhamnosus K3

\begin{tabular}{|l|c||}
\hline \multicolumn{1}{|c||}{ Tests / Testy } & Results / Wyniki \\
\hline Malonate utilization / Rozkład malonianu & - \\
\hline Acetoin production detection / Wykrywanie produkcji acetoiny & - \\
\hline Citrate utilization / Rozkład cytrynianu & - \\
\hline$\beta$-galactosidase activity / Aktywność $\beta$-galaktozydazy & + \\
\hline Nitrate reduction detection / Wykrywanie redukcji azotanów & - \\
\hline Catalase activity detection / Wykrywanie aktywności katalazy & - \\
\hline Arginine utilization / Rozkład argininy & - \\
\hline Saccharose utilization / Rozkład sacharozy & + \\
\hline Mannitol utilization / Rozkład mannitolu & + \\
\hline Glucose utilization / Rozkład glukozy & + \\
\hline Arabinose utilization / Rozkład arabinozy & + \\
\hline Trehalose utilization / Rozkład trehalozy & + \\
\hline Acidifying activity / Aktywność zakwaszająca $\Delta \mathrm{pH}$ & 1.49 \\
\hline
\end{tabular}

Explanatory notes / Objaśnienia:

$\mathrm{n}=3 ;(+)$ - positive reaction / reakcja pozytywna, $(-)$ - negative reaction / reakcja negatywna. 
Biochemical tests were applied to define the ability of microorganisms to metabolize, to produce the same compounds or to detect enzyme activity. The results of those biochemical tests are shown in Tab. 2.

The strain tested was able to degrade carbohydrates: sucrose, mannitol, glucose, arabinose and trehalose, which proved its high saccharolytic potential. The results of this research study are in line with the findings by Kuda et al. [14], who, in their paper, reported the ability of Lactobacillus to ferment sugars. However, Lb. rhamnosus K3 did not metabolize malonate, citrate and arginine. The Voges Proskauer's reaction showed that the strain did not produce acetoin. In their studies, Shakibaie et al. [26] also demonstrated that Lactobacillus strains had negative results in the Voges Proskauer's reaction. The $\beta$-galactosidase activity is particularly important for the fermentation of milk owing to the metabolism of lactose. Lactose maldigestion can be improved by the consumption of fermented milk products, which contain $\beta$-galactosidase in bacteria [18]. A high $\beta$-galactosidase activity of $L b$. rhamnosus $\mathrm{K} 3$ was observed and it was similar to the results obtained by Karasu et al. [13]. Lb. rhamnosus K3 did not utilize arginine and presented the absence of catalase activity, which was typical for the $L b$. rhamnosus species [7].

Lb. rhamnosus $\mathrm{K} 3$ was tested for survival in various environmental food media (Fig. 2). The MRS broth was used as a microbiological medium because it is a typical growth medium for Lactobacillus strains [22]. However, the highest viability was observed in milk (more than $11 \log \mathrm{CFU} / \mathrm{ml}$, statistically significant). The $\mathrm{pH}$ values of milk samples were similar to the $\mathrm{pH}$ value of MRS broth. Additionally, a high count of bacteria was found in the tomato juice (more than $9 \log \mathrm{CFU} / \mathrm{ml}$ ) and beef broth samples (more than $8 \log \mathrm{CFU} / \mathrm{ml}$, non-significant). Based on the results obtained, it can be concluded that the food medium was a good environment for Lb. rhamnosus $\mathrm{K} 3$.

Also, the ability of Lb. rhamnosus K3 to acidify milk was tested (Tab. 2). The value of $\Delta \mathrm{pH}$ was 1.49 and it indicated moderate properties of milk fermentation. LAB strains of different species are characterized by a different ability to acidify milk. Some LAB strains may exhibit an acidification ability value higher than 1.0 [5].

Due to the highest viability of the Lb. rhamnosus K3 strain in milk, this medium was chosen for further analyses. The optimal temperature of milk fermentation was set. The results are shown in Tab. 3. The highest number of bacterial cells was achieved during the fermentation at $37{ }^{\circ} \mathrm{C}$. Also the $\mathrm{pH}$ value was the lowest at $37{ }^{\circ} \mathrm{C}$ and it dropped from 6.71 to 4.65 . Under other temperature conditions of fermentation the numbers of bacterial cells were also high (more than $9 \log \mathrm{CFU} / \mathrm{ml}$ ). However, a product with the good sensory characteristics was expected, so it was decided to assume the highest number of bacterial cells and the lowest $\mathrm{pH}$ as a distinguishing quality. 


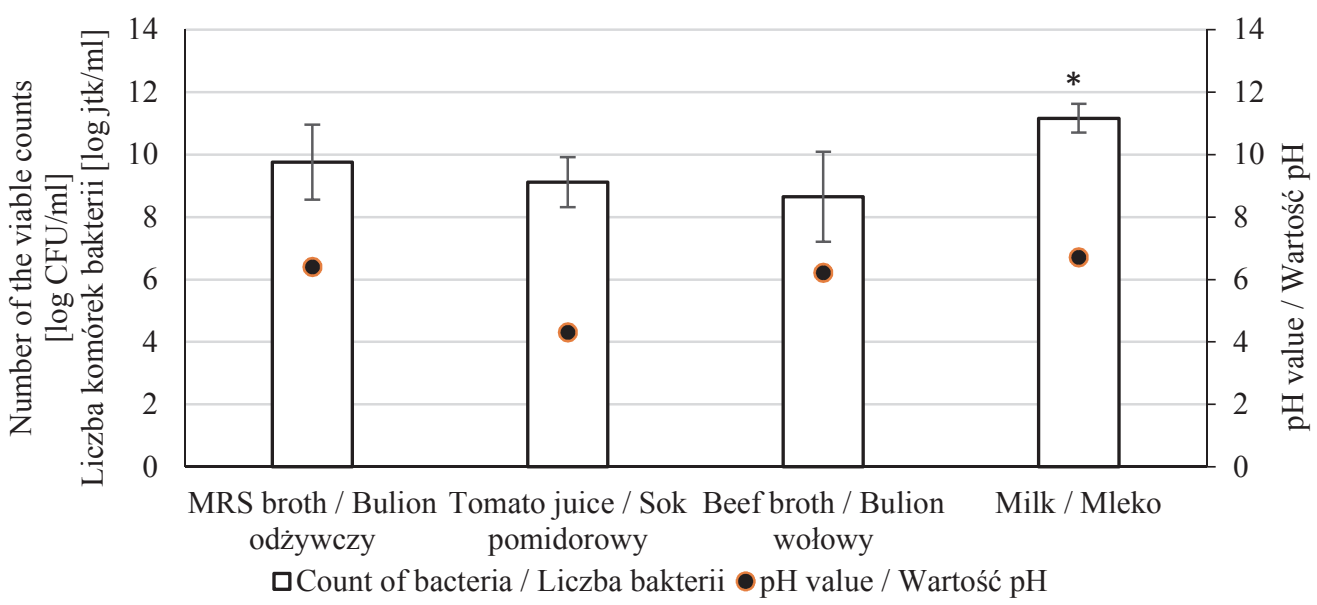

Explanatory notes / Objaśnienia:

Figure shows mean values (bars) and standard deviations (line segments) / Na rysunku przedstawiono wartości średnie (w postaci słupków) i odchylenia standardowe (w postaci odcinków); $\mathrm{n}=3 ;\left(^{*}\right)$ - statistically significant difference $(\mathrm{p}<0.05)$ / różnica statystycznie istotna $(\mathrm{p}<0,05)$.

Fig. 2. Growth of Lb. rhamnosus $\mathrm{K} 3$ strain depending on environmental medium Rys. 2. Wzrost szczepu Lb. rhamnosus K3 w zależności od środowiska

Table 3. Optimal temperature of milk fermentation for Lb. rhamnosus $\mathrm{K} 3$ strain Tabela 3. Optymalna temperatura fermentacji mleka dla szczepu Lb. rhamnosus $\mathrm{K} 3$

\begin{tabular}{|l|c|c|c||}
\hline \multirow{2}{*}{\multicolumn{1}{|c|}{ Item / Wyszczególnienie }} & \multicolumn{3}{|c||}{ Temperature / Temperatura $\left[{ }^{\circ} \mathrm{C}\right]$} \\
\cline { 2 - 4 } & 25 & 30 & 37 \\
\hline $\begin{array}{l}\text { Count of bacterial cells [log CFU/ml] } \\
\text { Liczba komórek bakterii }[\log \mathrm{jtk} / \mathrm{ml}]\end{array}$ & $9.47 \pm 0.01$ & $9.31 \pm 0.07$ & $9.76 \pm 0.05$ \\
\hline $\mathrm{pH}$ value / Wartość $\mathrm{pH}$ & $5.430 \pm 0.002$ & $5.010 \pm 0.000$ & $4.650 \pm 0.003$ \\
\hline
\end{tabular}

Explanatory notes as in Tab. 1. / Objaśnienia jak pod tab. 1.

Lb. rhamnosus $\mathrm{K} 3$ maintained a statically significant high number of bacterial cells during the whole period of refrigeration storage at $4{ }^{\circ} \mathrm{C}(8 \log \mathrm{CFU} / \mathrm{ml})-$ Fig. 3 . A slight decrease was observed in the number of bacterial cells after 4 weeks of storage. According to FIL/IDF [4] and FAO/WHO [2] guidelines, the basic starter microflora (i.e. yoghurt) and additional microflora (i.e. probiotic) must maintain a high number of viable cells. On the last day of shelf life, the count of lactic acid bacteria should not be lower than $6 \log \mathrm{CFU} / \mathrm{ml}$. This value is considered and called the "minimum therapeutic" and it applies to refrigerated products. The $\mathrm{pH}$ value was maintained at the same level during the whole period of storage and it equalled approximately 4 (Fig. 4). At $25^{\circ} \mathrm{C}$ the number of Lb. rhamnosus was still high and remained at a level of at $9 \log$ $\mathrm{CFU} / \mathrm{ml}$ for 3 weeks. Then it slightly decreased to over $7 \log \mathrm{CFU} / \mathrm{ml}$ after 6 -week 
storage. Despite a relatively low pH (3.59), the product' quality was still high after 6 weeks of storage. Meanwhile a statistically significant reduction in number of LAB was observed at $37^{\circ} \mathrm{C}$ just after 2 weeks of storage. The number of bacteria below $6 \log \mathrm{CFU} / \mathrm{ml}$ suggested a drop in the milk quality to an unacceptable level. At $37^{\circ} \mathrm{C}$ the milk fermentation was continuous. The number of LAB began to sharply drop as a result of the lack of minerals or owing to poisoning by their own metabolites. A continuous production of lactic acid caused a statistically insignificant reduction in $\mathrm{pH}$ (3.58). Based on the study results, it was found that the optimum storage temperature was $4{ }^{\circ} \mathrm{C}$, though the temperature of $25^{\circ} \mathrm{C}$ also guaranteed a high product quality (Fig. 3).

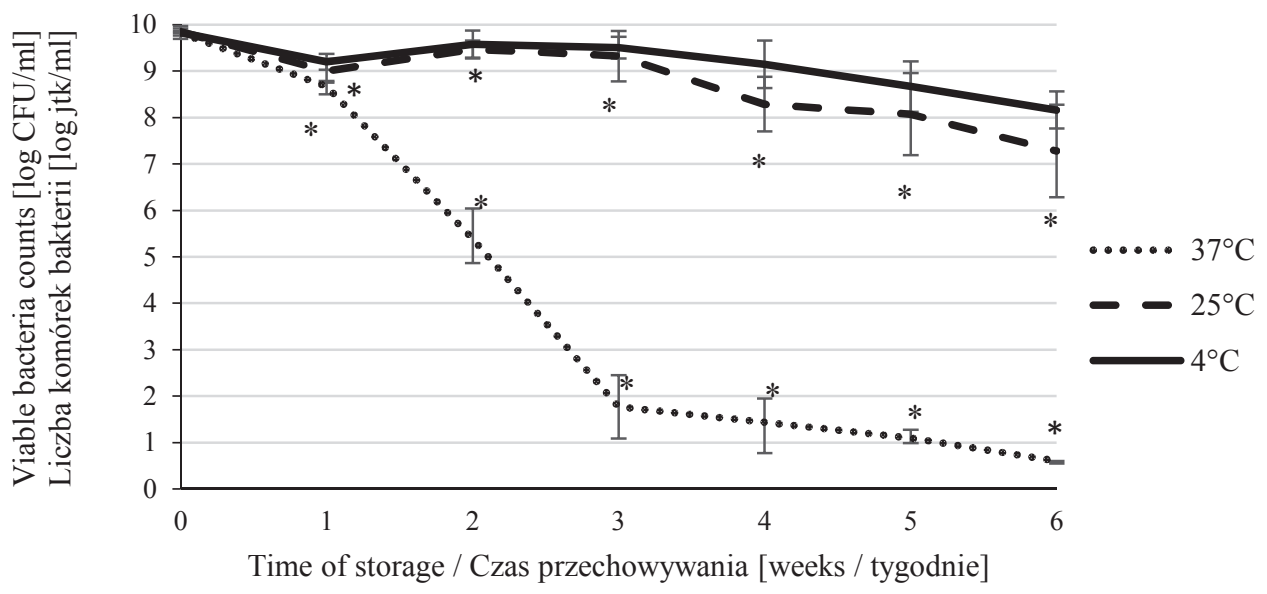

Explanatory notes as in Fig. 2. / Objaśnienia jak pod rys. 2.

Fig. 3. Survival rate of $L b$. rhamnosus $\mathrm{K} 3$ strain in fermented milk

Rys. 3. Przeżywalność szczepu Lb. rhamnosus K3 w mleku fermentowanym

The study results were similar to those reported by Innocente et al. [9]. The $L b$. rhamnosus DSA LR1 strain was used with traditional yogurt starter cultures. At $4{ }^{\circ} \mathrm{C}$ and after 20 days of storage the viability of the bacteria exceeded $8 \log \mathrm{CFU} / \mathrm{ml}$. According to Zamberlin \& Samaržija [28] Lb. rhamnosus GG in conjunction with the traditional yoghurt starter culture retained a high viability of bacteria at $4{ }^{\circ} \mathrm{C}$ after 21 days of storage in the yogurt made from sheep's milk. It was proved that the Lb. rhamnosus species could be used as a starter culture or as an addition to the traditional starter culture. In the Settachaimongkon et al. study [24, 25] it was reported that Lb. rhamnosus GG showed a very good survival rate in the set-yogurt and its bacterial cells were stable from the beginning of fermentation throughout the entire period of refrigeration storage (at $4 \pm 2{ }^{\circ} \mathrm{C}$ ). According to Jia et al. [11] Lb. rhamnosus $\mathrm{GG}$ can be 
used as a starter culture with a yogurt starter culture in the goat's milk yogurt. Jałosińska [10] conducted research studies on the survival of the probiotic strain of Lactobacillus casei KNE-1 in a banana-dairy drink. During storage at a reduced temperature the number of lactic bacteria remained at a high level, while the $\mathrm{pH}$ value decreased.

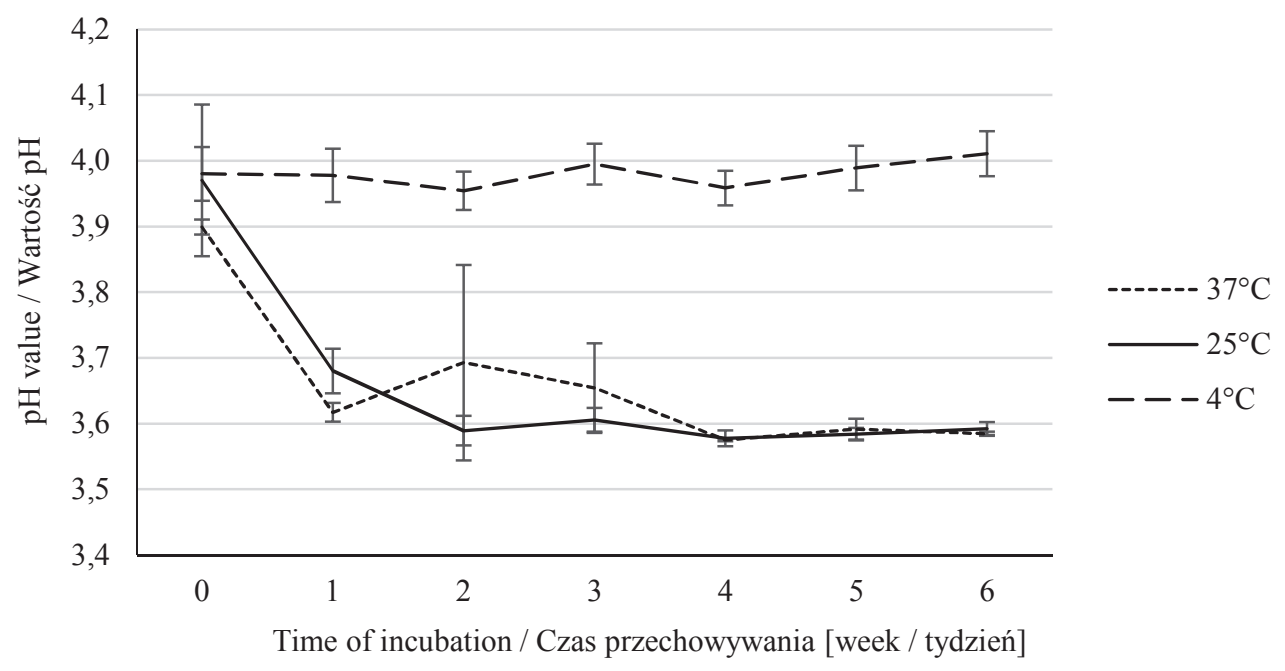

Explanatory notes as in Fig. 2. / Objaśnienia jak pod rys. 2.

Fig. 4. $\quad \mathrm{pH}$ value of fermented milk with Lb. rhamnosus $\mathrm{K} 3$ strain

Rys. 4. Wartość pH mleka fermentowanego przez Lb. rhamnosus K3

Consumers are looking for foods with added value, which will have a positive impact on the functioning of their bodies. Therefore, research is needed to confirm the positive effect of probiotic bacteria on human health. In addition, with the development of food industry, there is a need to select new bacterial cultures. The bacteria isolated from GIT are often too weak to carry out technological processes. The isolation of bacteria from spontaneously fermented food and testing them for functional properties makes it possible to use beneficial strains as starter cultures. The authors' own study indicated that $L b$. rhamnosus $\mathrm{K} 3$ can be used as a food starter culture owing to its appropriate growth during fermentation and a good survival rate during refrigeration storage. However, further studies should be conducted. 


\section{Conclusions}

1. The Lb. rhamnosus $\mathrm{K} 3$ strain was able to grow at different temperatures, but in a narrow $\mathrm{pH}$ range. The bacterial strain did not tolerate high $\mathrm{NaCl}$ concentrations, however it grew well in any kind of food medium.

2. Lb. rhamnosus $\mathrm{K} 3$ was able to metabolize sugars. The strain did not reduce nitrates and no catalase activity was detected. The presence of $\beta$-galactosidase enzyme was reported.

3. The best temperature for milk to ferment was $37^{\circ} \mathrm{C}$. The number of bacterial cells maintained at a level higher than $8 \log \mathrm{CFU} / \mathrm{ml}$ throughout the whole period of refrigeration storage.

4. The research study reveals that the Lb. rhamnosus $\mathrm{K} 3$ strain isolated from fermented cabbage has high potential for food applications, because the strain proves to be well-adapted to a particular environment and it can be adapted to specific manufacturing technology.

\section{References}

[1] Casaburi A., Di Martino V., Ferranti P., Picariello L., Villani F.: Technological properties and bacteriocins production by Lactobacillus curvatus 54M16 and its use as starter culture for fermented sausage manufacture. Food Control, 2016, 59, 31-45.

[2] FAO/WHO Codex Alimentarius Commission: Annex Proposed Draft Standard for Fermented Milks (A11) CL 1997, MMP 12.

[3] Ferrando V., Quiberoni A., Reinheimer J., Suárez V.: Functional properties of Lactobacillus plantarum strains: A study in vitro of heat stress influence. Food Microbiol., 2016, 54, 154-161.

[4] FIL/IDF, Commission D-Legislation: Standards of Identity Terminology Fermented Milk Products. 1997, Doc. 316.

[5] Floros G., Hatzikamari M., Litopoulou-Tzanetaki E., Tzanetakis N.: Probiotic and technological properties of facultatively heterofermentative lactobacilli from Greek traditional cheeses. Food Biotechnol., 2012, 26, 85-105.

[6] Frece J., Vrdoljak M., Filipčić M., Jelić M., Čanak I., Jakopović Ž., Pleadin J., Gobin I., Dragičević T.L., Markov K.: Microbiological quality and variability of natural microbiota in Croatian cheese maturing in lambskin sacks. Food Technol. Biotechnol., 2016, 54(2), 129-134.

[7] Hammes W.P., Hertel C., Genus I.: Lactobacillus. In.: Bergey's Manual of Systematic Bacteriology. Vol. 3. The Firmicutes. $2^{\text {nd }}$ ed. Eds. W.B. Whitman. Springer, New York, USA, 2009, pp. 465-510.

[8] Holzapfel W.H.: Appropriate starter culture technologies for small-scale fermentation in developing countries. Int. J. Food Microbiol., 2002, 75(3), 197-212.

[9] Innocente N., Biasutti M., Rita F., Brichese R., Comi G., Iacumin L.: Effect of indigenous Lactobacillus rhamnosus isolated from bovine milk on microbiological characteristics and aromatic profile of traditional yogurt. LWT - Food Sci. Technol., 2016, 66, 158-164.

[10] Jałosińska M.: Przeżywalność szczepu probiotycznego w napoju bananowo-mlecznym w zależności od dodatku różnych prebiotyków. Żywność Nauka Technologia Jakość, 2007, 6 (55), 127-137.

[11] Jia R., Chen H., Chen H., Ding W.: Effects of fermentation with Lactobacillus rhamnosus GG on product quality and fatty acids of goat milk yogurt. J. Dairy Sci., 2016, 99 (1), 221-227. 
[12] Jonkuviene D., Vaičiulyte-Funk L., Šalomskiene J., Alenčikiene G., Mieželiene A.: Potential of Lactobacillus reuteri from spontaneous sourdough as a starter additive for improving quality parameters of bread. Food Technol. Biotechnol., 2016, 54(3), 342-350.

[13] Karasu N., Şimșek Ö., Çon A.H.: Technological and probiotic characteristics of Lactobacillus plantarum strains isolated from traditionally produced fermented vegetables. Ann. Microbiol., 2010, 60(2), 227-234.

[14] Kuda T., Kataoka M., Nemoto M., Kawahara M., Takahashi H., Kimura B.: Isolation of lactic acid bacteria from plants of the coastal Satoumi regions for use as starter cultures in fermented milk and soymilk production. LWT - Food Sci. Technol., 2016, 68, 202-207.

[15] Morita H., Toh H., Oshima K., Murakami M., Taylor T.D., Igimi S., Hattori M.: Complete genome sequence of the probiotic Lactobacillus rhamnosus ATCC 53103. J. Bacteriol., 2009, 191(24), 76307631.

[16] Neffe-Skocińska K., Kołożyn-Krajewska D.: Sposób przygotowania szczepionki bakterii probiotycznych jako kultury startowej w produktach mięsnych. Polska, Opis patentowy 2014, 226236.B1.

[17] Ng S.Y., Koon S.S., Padam B.S., Chye F.Y.: Evaluation of probiotic potential of lactic acid bacteria isolated from traditional Malaysian fermented Bambangan (Mangiferapajang). CyTA - J. Food, 2015, 13(4), 563-572.

[18] Pinto M.G.V., Franz C.M., Schillinger U., Holzapfel W.H.: Lactobacillus spp. with in vitro probiotic properties from human faeces and traditional fermented products. Int. J. Food Microbiol., 2006, 109(3), 205-214.

[19] PN-ISO 15214:2002. Mikrobiologia żywności i pasz. Horyzontalna metoda oznaczania liczby mezofilnych bakterii fermentacji mlekowej. Metoda płytkowa w temperaturze 30 stopni C.

[20] Ruiz P., Barragán I., Seseña S., Palop M.L.: Functional properties and safety assessment of lactic acid bacteria isolated from goat colostrum for application in food fermentations. Int. J. Dairy Technol., 2016, 69(4), 559-568.

[21] Sahnouni F., Ringø E., Maizi A., Matallah-Boutiba S.B.A., Chemlal D., Boutiba Z.: Biochemical and antibacterial potential of autochthonous Carnobacterium and Lactobacillus species isolated from gastrointestinal tract of coastal fish. J. Anim. Plant Sci., 2016, 26(4), 1146-1155.

[22] Schillinger U., Holzapfel W.H.: Culture media for lactic acid bacteria. In.: Progress in Industrial Microbiology. Vol. 37. Handbook of Culture Media for Food Microbiology. Elsevier, Amsterdam 2003, pp. 127-140.

[23] Schillinger U., Lücke F.K.: Identification of lactobacilli from meat and meat products. Food Microbiol, 1987, 4(3), 199-208.

[24] Settachaimongkon S., Nout M.R., Fernandes E.C.A., van Hooijdonk T.C., Zwietering M.H., Smid E.J., van Valenberg H.J.: The impact of selected strains of probiotic bacteria on metabolite formation in set yoghurt. Int. Dairy J., 2014, 38(1), 1-10.

[25] Settachaimongkon S., van Valenberg H.J., Gazi I., Nout M.R., van Hooijdonk T.C., Zwietering M.H., Smid E.J.: Influence of Lactobacillus plantarum WCFS1 on post-acidification, metabolite formation and survival of starter bacteria in set-yoghurt. Food Microbiol., 2016, 59, 14-22.

[26] Shakibaie M., Mohammadi-Khorsand T., Adeli-Sardou M., Jafari M., Amirpour-Rostami S., Ameri A., Forootanfar H.: Probiotic and antioxidant properties of selenium-enriched Lactobacillus brevis LSe isolated from an Iranian traditional dairy product. J. Trace Elem. Med. Bio., 2017, 40, 1-9.

[27] Tortora G.J., Funke B.R., Case C.L.: Microbial growth. In.: Microbiology and Introduction. Eds. G.J. Tortora, B.R. Funke., C.L. Case. Pearson, New York, 2013, pp. 153-180.

[28] Zamberlin Š., Samaržija D.: The effect of non-standard heat treatment of sheep's milk on physicochemical properties, sensory characteristics, and the bacterial viability of classical and probiotic yogurt. Food Chem., 2017, 225, 62-68. 
[29] Zielińska D., Rzepkowska A., Radawska A., Zieliński K.: In vitro screening of selected probiotic properties of Lactobacillus strains isolated from traditional fermented cabbage and cucumber. Curr. Microbiol., 2015, 70(2), 183-194.

\title{
WŁAŚCIWOŚCI TECHNOLOGICZNE SZCZEPU LACTOBACILLUS RHAMNOSUS K3 WYIZOLOWANEGO Z KISZONEJ KAPUSTY I JEGO POTENCJALNE WYKORZYSTANIE JAKO KULTURY STARTOWEJ DO ŻYWNOŚCI FERMENTOWANEJ
}

\author{
Streszczenie
}

Celem pracy było określenie właściwości technologicznych szczepu Lactobacillus rhamnosus K3. Oceniono zdolność szczepu do wzrostu w warunkach - temperatura $\left[{ }^{\circ} \mathrm{C}\right]: 10,15,45 ; \mathrm{pH}$ środowiska: 3,9 ; 6,4; 9,6; stężenie soli [\%]: 5, 8, 10. Wykonano testy biochemiczne (fermentacja cukrów, aktywność enzymów), oceniono przeżywalność szczepu w zależności od matrycy żywnościowej (w mleku, soku pomidorowym i bulionie wołowym). Wyznaczono optymalną temperaturę fermentacji mleka i sprawdzono przeżywalność podczas 6-tygodniowego przechowywania. W wyniku przeprowadzonych badań stwierdzono, że szczep $L$ b. rhamnosus K3 był zdolny do wzrostu w szerokim zakresie temperatur, ale w wąskim zakresie $\mathrm{pH}$ środowiska. Szczep nie tolerował wysokiego stężenia $\mathrm{NaCl}$, ale był zdolny do wzrostu w każdym rodzaju medium żywnościowego. Największy wzrost bakterii zaobserwowano w mleku. Lb. rhamnosus K3 metabolizował większość cukrów. Nie stwierdzono redukcji azotanów. Szczep K3 jest katalazoujemny. Stwierdzono aktywność enzymu $\beta$-galaktozydazy. Optymalną temperaturą fermentacji mleka było $37^{\circ} \mathrm{C}$. Stwierdzono przydatność technologiczną szczepu Lb. rhamnosus K3 jako kultury startowej do mleka. Podczas chłodniczego przechowywania $\left(\mathrm{w} 4{ }^{\circ} \mathrm{C}\right)$ liczba komórek bakterii utrzymywała się powyżej $8 \mathrm{log}$ jtk/ml. Szczep Lactobacillus rhamnosus K3 był zdolny do prowadzenia fermentacji, co czyni go przydatnym technologicznie do produkcji mlecznych wyrobów fermentowanych.

Słowa kluczowe: bakterie fermentacji mlekowej (LAB), Lactobacillus rhamnosus, właściwości technologiczne, żywność fermentowana 